\title{
Fatty acid composition of the adipose tissue of polar bears and of their prey: ringed seals, bearded seals and harp seals
}

\author{
Otto Grahl-Nielsen ${ }^{1, *}$, Magnus Andersen ${ }^{2}$, Andrew E. Derocher ${ }^{2,4}$, \\ Christian Lydersen ${ }^{2}$, Øystein Wiig $^{3}$, Kit M. Kovacs ${ }^{2}$ \\ ${ }^{1}$ Department of Chemistry, University of Bergen, 5007 Bergen, Norway \\ ${ }^{2}$ Norwegian Polar Institute, 9296, Tromsø, Norway \\ ${ }^{3}$ Zoological Museum, University of Oslo, PO Box 1172 Blindern, 0318 Oslo, Norway \\ ${ }^{4}$ Present address: Department of Biological Sciences, University of Alberta, Edmonton T6G 2E9, Canada
}

\begin{abstract}
Polar bears Ursus maritimus are predators of phocid seals, but they also forage opportunistically on a variety of other species. In the Barents Sea - Svalbard area, their diet is thought to consist almost exclusively of ringed seals Phoca hispida, bearded seals Erignathus barbatus and harp seals $P$. groenlandica. When a seal is killed, polar bears preferentially consume the blubber. The fatty acid (FA) compositions of the outer, middle and inner adipose layer of 18 polar bears were compared to each other and also with the FA composition of the blubber of their prey, represented by 10 ringed seals, 10 harp seals and 9 bearded seals. The composition of the FAs in the inner layer of the bear adipose tissue differed from the composition of the outer layer, and was also distinctly different from the composition of the blubber from the prey. Fifteen of the 28 FAs analysed were found in lower relative amounts in the polar bears than in any of the 3 seal species. Eight of the FAs were found in higher relative amounts in polar bears when compared to the 3 prey species. Only 5 of the FAs in polar bears were within the range of relative values found in the prey. This strongly suggests that polar bear adipose tissue has a unique FA composition that is not a straightforward mixture of what they consume, but rather is the result of selective processes prior to and during deposition of lipids in the tissue.
\end{abstract}

KEY WORDS: Polar bear $\cdot$ Adipose tissue $\cdot$ Fatty acid composition $\cdot$ Prey $\cdot$ Seal $\cdot$ Blubber

\section{INTRODUCTION}

The use of fatty acid (FA) signature analyses has been proposed as a method for determining the diet of marine mammals (e.g. Iverson 1993, Iverson et al. 1997). The underlying principle of this method is the assumption that FAs in prey species are incorporated, more or less unmodified, into the adipose tissue of the predator. To assess the diet of a predator, the FA signature from its adipose tissue can be compared to the FA signatures from potential prey species. This method has recently been used to study the diet of a variety of marine mammals, including harbour seals
Phoca vitulina (Iverson et al. 1997), gray seals Halichoerus grypus (Walton et al. 2000) and beluga whales Delphinapterus leucas (Dahl et al. 2000). However, some studies suggest that FA profiles in the blubber or adipose tissues of a species cannot be used reliably as a means to determine its diet (Grahl-Nielsen et al. 2000).

Polar bears are at the top of the marine food chain in the arctic, and feed largely on ringed seals Phoca hispida, bearded seals Erignathus barbatus, and harp seals P. groenlandica (Lønø 1970, Stirling \& Archibald 1977, Derocher et al. 2002) in the North Atlantic region. Polar bears feed little from late summer through win- 
ter, with the peak feeding period occuring in spring and early summer when substantial adipose deposits are formed (Watts \& Hansen 1987, Ramsay \& Stirling 1988).

No detailed studies on polar bear diets are available. Most of our knowledge regarding the polar bear diet is derived from field observations of animals killed by bears (Stirling \& McEwan 1975, Hammill \& Smith 1991, Derocher et al. 2002) or from stomach contents of polar bears (Lønø 1970).

Polar bears preferentially consume the blubber of seals (Stirling \& McEwan 1975). Sampling of the bears adipose tissue and of blubber from various seal species could provide an opportunity to apply the FA method to identify the bears' diet. Iverson et al. (1999) reported preliminary results on a study of geographic variation in the diet of polar bears by the use of fatty acids.

FA composition of polar bear adipose tissue has not been well described, but some investigations on wild and captive bears have been conducted (Pond et al. 1992, Colby et al. 1993). The proportions of FA in polar bear adipose tissue were found to be significantly different from those reported in the blubber of ringed seals, considered to be their principal prey (Pond et al. 1992). The biochemical properties of the adipose tissue in polar bears was found not to be adapted to thermal insulation. But there was some evidence that the FA composition was adapted to low skin temperatures (Pond et al. 1992).

The aims of the present investigation were: (1) to describe the FA composition of adipose tissue of polar bears in greater detail than has been previously reported; (2) to determine whether the FA composition varies with depth within the adipose layer of polar bears, as is the case for the blubber of seals and whales; and (3) to compare the FA profiles of polar bears with the FA profiles of their 3 main prey species of seals, in order to explore the possibility of using FAs to determine the diet of polar bears.

\section{MATERIALS AND METHODS}

Field methods. Bears were captured in the Svalbard area $\left(76-80^{\circ} \mathrm{N}, 22-29^{\circ} \mathrm{E}\right)$ in mid-April 1999 by remote injection of a drug-filled dart (Palmer Cap-Chur Equipment) fired from a helicopter. The drug Zoletil vet $^{\circledR}$ (Virbac International) was administered in a solution of $200 \mathrm{mg} \mathrm{ml}^{-1}$ at a dosage of 5 to $10 \mathrm{mg} \mathrm{kg}^{-1}$ of body mass (Stirling et al. 1989). The sex and reproductive status were documented for each bear. A rudimentary premolar tooth was extracted from all bears for age determination (Calvert and Ramsay 1998). The 18 bears in this investigation were between 2 and $21 \mathrm{yr}$ of age. Adipose tissue samples were collected using a sterile biopsy punch (6 $\mathrm{mm}$ diameter) from the rump fat depots to the side of the tail. Efforts were made to obtain as deep a fat core as possible from each bear, but the tissue samples were often loosely connected at depth, and in a few instances the cores broke. This increased the possibility of cross-contamination of lipid material along the core, and made it difficult to keep track of the various core layers. The samples were wrapped in tin foil, and placed in a sterile glass container and stored frozen until analysis.

Harp seals $(n=10)$, ringed seals $(n=10)$ and bearded seals $(n=9)$ were collected from seals that were shot along the ice edge in the Greenland Sea (west of Svalbard), Barents Sea (east of Svalbard) and the Arctic Ocean (north of Svalbard) during 1999 and 2000. Blubber samples were taken from 5 to $10 \mathrm{~cm}^{2}$ sections collected through the whole layer of the blubber, from skin surface down to the muscle, mid-dorsally at approximately $40 \%$ of the distance between snout and tail. The samples were wrapped carefully in aluminium foil, then plastic, and stored frozen until analysis.

All animal handling methods were approved by the National Animal Research Authority of Norway (NARA; Norwegian Animal Health Authority).

Laboratory methods. Subsamples of adipose tissue from the bears and blubber from the seals were taken for chemical analysis while the tissues were frozen. From the bears, 2 parallel sets of subsamples, each individual sample weighing between 10 and $20 \mathrm{mg}$, were taken next to the skin, next to the muscle and midway between. From the seal blubber, a minimum of 8 subsamples, 4 from the inner and 4 from the outer blubber layer, to cover the total blubber depth, were taken from each individual. All subsamples were subjected to methanolysis in thick-walled glass tubes with Teflon-lined screw caps, using $0.5 \mathrm{ml}$ dry methanol containing $2 \mathrm{M} \mathrm{HCl}$, for $2 \mathrm{~h}$ at $90^{\circ} \mathrm{C}$. After methanolysis, approximately half the methanolic $\mathrm{HCl}$ solution was evaporated off using nitrogen gas. Distilled water $(0.5 \mathrm{ml})$ was added to the sample and the FA methyl esters were extracted twice with $1 \mathrm{ml}$ hexane.

Of the mixed hexane extracts, $1 \mu \mathrm{l}$ were subjected to chromatography on a $25 \mathrm{~m} \times 0.25 \mathrm{~mm}$ fused silica column with polyethyleneglycol as the stationary phase, with a thickness of $0.2 \mathrm{~mm}$ (CP-WAX 52CB Chrompack), and helium at 20 psi as the mobile phase. The column was mounted in a Hewlett-Packard 5890A gas chromatograph, equipped with a Hewlett-Packard 7673A autosampler and a flame-ionisation detector. The injector temperature was $260^{\circ} \mathrm{C}$. The temperature of the column was kept at $90^{\circ} \mathrm{C}$ for 4 min after splitless injection, and thereafter increased to $165^{\circ} \mathrm{C}$ at a rate of $30^{\circ} \mathrm{C} \mathrm{min}{ }^{-1}$, followed by an increase of $3^{\circ} \mathrm{C} \mathrm{min}^{-1}$ to $225^{\circ} \mathrm{C}$. This temperature was maintained for $10.5 \mathrm{~min}$. The flame ionisation detector was set at $330^{\circ} \mathrm{C}$. Samples 
were analyzed in random order, with a standard solution, GLC-68D (Nu-Chek-Prep), that contained 20 FA methyl esters between every $8 \mathrm{~h}$ sample. Altogether, 28 FAs were identified in the samples using the standard mixture and mass spectrometry. The peaks were integrated by Atlas 2000 software (Thermo Labsystems), and the peak areas were corrected according to response factors determined from the 20 FA methyl esters present in the standard mixture, and by estimation via use of chain length and number of double bonds for the 8 FA methyl esters not present in the standard mixture. The amount of each FA in a sample was expressed as a percent of the sum of all FAs in the sample.

Statistical methods. To obtain the combined information from all 28 FAs simultaneously, the data were subjected to multivariate principal component analysis (PCA). The relative values of the FAs were logarithmically transformed, thereby leveling out the quantitative differences among fatty acids. With each sample positioned in the multi-dimensional space described by the log-transformed variables (fatty acids), the 2 axes (principal components, PC) that described the largest (PC1) and second largest (PC2) sources of variance among the samples were computed using SIRIUS software (Kvalheim \& Karstang 1987).

To quantify the observed difference between the various prey samples and the samples from the inner adipose layer of the polar bears, a space-filling model for the bear samples was built by the program SIMCA (Soft Independent Modeling of Class Analogies) (Wold 1976; Wold 1978; Ugland and Massart 1996), available in the SIRIUS software package. The model was based on 2 PCs of the inner adipose tissue samples. The distance of all other samples to this model was then computed as residual standard deviation, RSD.

\section{RESULTS}

The FA composition in the adipose tissue of polar bears and the blubber of the 3 species of phocid seals had a typically marine pattern, with relatively high amounts of monounsaturated and polyunsaturated n3 fatty acids (Table 1, Fig. 1). There were large differences among individuals within each species, resulting in high SDs of the mean values.

The inner and middle layer of polar bear adipose tissue had a similar FA composition, while the outer layer differed from the other 2 layers. However, only 10 of the 28 FAs occurred in significantly different amounts in the inner compared to the outer layer $(p<0.01$, Table 1$)$. The FAs with the largest differences were 22:1n11 and 22:1n9, with higher values in the inner layer, and 20:4n6 with lower values in the inner layer. In addition, 20:1n9

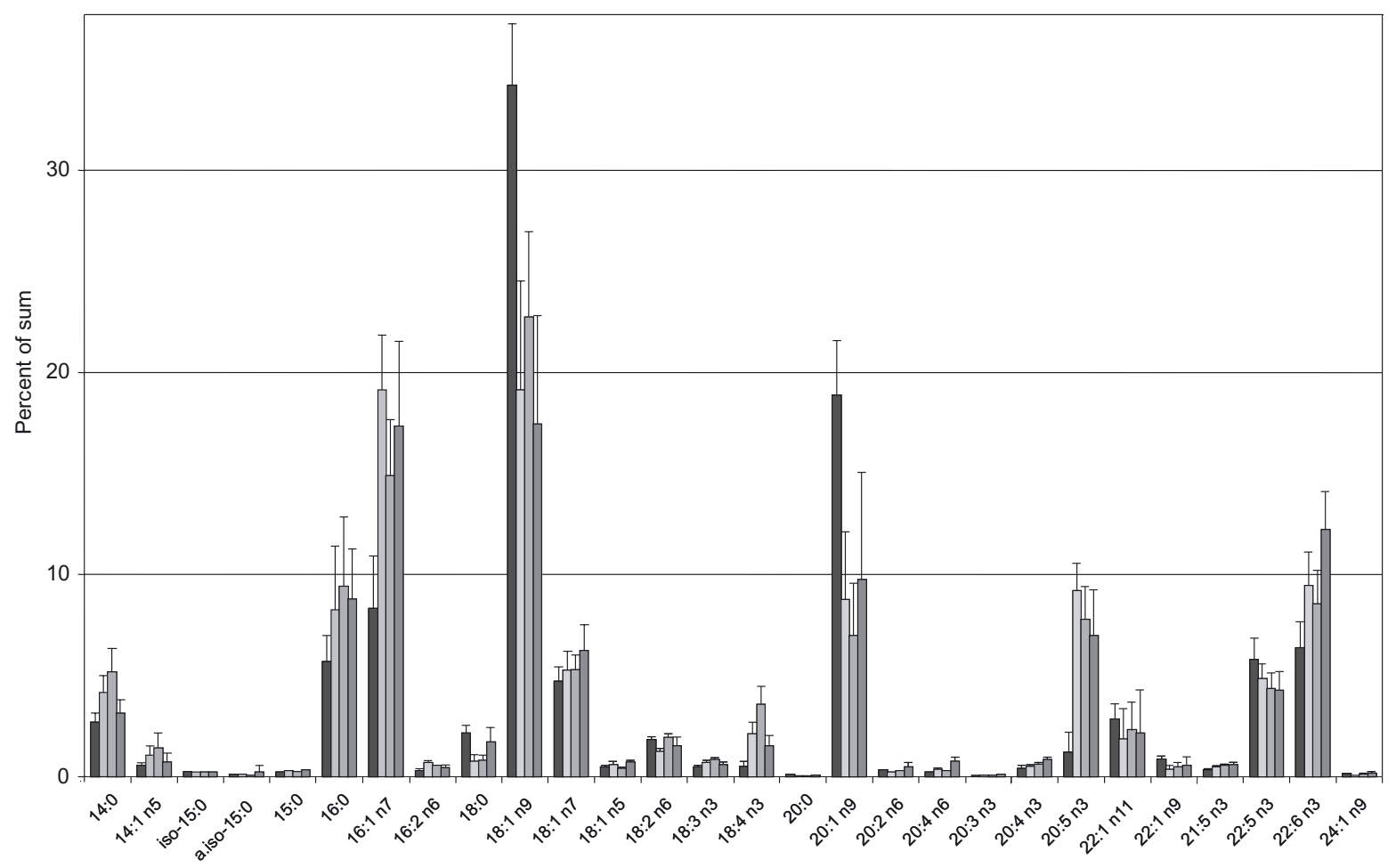

Fig. 1. Ursus maritimus, Phoca hispida, Phoca groenlandica and Erignathus barbatus. Average relative amounts of the fatty acids (from left to right for each fatty acid) in the inner adipose tissue layer of polar bears $(2 \times 18$ samples), and in the blubber of ringed seals (90 samples from 10 animals), harp seals (195 samples from 10 animals), and bearded seals (125 samples from 9 animals). Values are means + SD 
Table 1. Ursus maritimus, Phoca hispida, Phoca groenlandica and Erignathus barbatus. Average amounts of fatty acids, as percentage of sum $\pm \mathrm{SD}$, in the inner, middle and outer blubber layer of polar bears, based on 2 parallel samples from each layer from each of 18 bears, in the blubber of ringed seals, based on 90 samples from 10 individuals, in the blubber of harp seals, based on 195 samples from 10 individuals, and in the blubber of bearded seals, based on 125 samples from 9 individuals. The inequality signs are given for the fatty acids where there is a significant difference, $p<0.01$, between the inner and outer blubber layer of polar bears

\begin{tabular}{|c|c|c|c|c|c|c|c|}
\hline Fatty acid & Inner & $\begin{array}{l}\text { - Polar bear } \\
\text { Middle }\end{array}$ & & Outer & Ringed seal & Harp seal & Bearded seal \\
\hline $14: 0$ & $2.7 \pm 0.5$ & $2.8 \pm 0.5$ & & $2.5 \pm 0.5$ & $4.2 \pm 0.8$ & $5 \pm 1$ & $3.2 \pm 0.7$ \\
\hline $14: 1 \mathrm{n} 5$ & $0.5 \pm 0.2$ & $0.5 \pm 0.1$ & & $0.6 \pm 0.2$ & $1.1 \pm 0.5$ & $1.4 \pm 0.8$ & $0.7 \pm 0.4$ \\
\hline iso-15:0 & $0.25 \pm 0.05$ & $0.26 \pm 0.05$ & & $0.25 \pm 0.05$ & $0.23 \pm 0.03$ & $0.22 \pm 0.04$ & $0.21 \pm 0.05$ \\
\hline a.iso-15:0 & $0.11 \pm 0.03$ & $0.11 \pm 0.02$ & $>$ & $0.09 \pm 0.02$ & $0.09 \pm 0.02$ & $0.08 \pm 0.01$ & $0.2 \pm 0.4$ \\
\hline $15: 0$ & $0.21 \pm 0.06$ & $0.21 \pm 0.05$ & $<$ & $0.29 \pm 0.06$ & $0.28 \pm 0.04$ & $0.24 \pm 0.05$ & $0.35 \pm 0.05$ \\
\hline $16: 0$ & $5 \pm 1$ & $6 \pm 1$ & $<$ & $7 \pm 1$ & $8 \pm 3$ & $9 \pm 3$ & $9 \pm 2$ \\
\hline $16: 1 \mathrm{n} 7$ & $8 \pm 3$ & $8 \pm 3$ & & $10 \pm 3$ & $19 \pm 3$ & $15 \pm 3$ & $17 \pm 4$ \\
\hline $16: 2 \mathrm{n} 6$ & $0.3 \pm 0.1$ & $0.3 \pm 0.1$ & & $0.31 \pm 0.09$ & $0.7 \pm 0.1$ & $0.54 \pm 0.06$ & $0.5 \pm 0.1$ \\
\hline 18:0 & $2.2 \pm 0.4$ & $2.3 \pm 0.4$ & $<$ & $2.5 \pm 0.5$ & $0.8 \pm 0.3$ & $0.8 \pm 0.3$ & $1.7 \pm 0.7$ \\
\hline $18: 1 \mathrm{n} 9$ & $34 \pm 5$ & $34 \pm 5$ & & $35 \pm 5$ & $19 \pm 5$ & $23 \pm 4$ & $17 \pm 5$ \\
\hline $18: 1 \mathrm{n} 7$ & $4.7 \pm 0.7$ & $4.8 \pm 0.7$ & $<$ & $5.4 \pm 0.9$ & $5 \pm 1$ & $5.3 \pm 0.8$ & $6 \pm 1$ \\
\hline $18: 1 \mathrm{n} 5$ & $0.47 \pm 0.08$ & $0.47 \pm 0.09$ & & $0.50 \pm 0.08$ & $0.6 \pm 0.2$ & $0.40 \pm 0.09$ & $0.7 \pm 0.1$ \\
\hline $18: 2 \mathrm{n} 6$ & $1.8 \pm 0.2$ & $1.8 \pm 0.2$ & & $1.8 \pm 0.2$ & $1.2 \pm 0.2$ & $1.9 \pm 0.2$ & $1.5 \pm 0.4$ \\
\hline $18: 3 n 3$ & $0.48 \pm 0.08$ & $0.48 \pm 0.08$ & & $0.48 \pm 0.09$ & $0.7 \pm 0.1$ & $0.9 \pm 0.1$ & $0.6 \pm 0.1$ \\
\hline $18: 4 \mathrm{n} 3$ & $0.5 \pm 0.3$ & $0.5 \pm 0.3$ & & $0.4 \pm 0.3$ & $2.1 \pm 0.6$ & $3.6 \pm 0.9$ & $1.5 \pm 0.5$ \\
\hline $20: 0$ & $0.11 \pm 0.02$ & $0.11 \pm 0.03$ & & $0.12 \pm 0.05$ & $0.04 \pm 0.01$ & $0.05 \pm 0.02$ & $0.07 \pm 0.03$ \\
\hline $20: 1 n 9$ & $19 \pm 3$ & $18 \pm 3$ & $>$ & $15 \pm 3$ & $9 \pm 3$ & $7 \pm 3$ & $10 \pm 5$ \\
\hline $20: 2 \mathrm{n} 6$ & $0.32 \pm 0.05$ & $0.33 \pm 0.05$ & & $0.31 \pm 0.04$ & $0.20 \pm 0.04$ & $0.28 \pm 0.06$ & $0.5 \pm 0.2$ \\
\hline $20: 4 n 6$ & $0.21 \pm 0.05$ & $0.21 \pm 0.04$ & $<$ & $0.4 \pm 0.2$ & $0.37 \pm 0.08$ & $0.31 \pm 0.04$ & $0.8 \pm 0.2$ \\
\hline $20: 3 n 3$ & $0.06 \pm 0.02$ & $0.06 \pm 0.02$ & & $0.05 \pm 0.02$ & $0.08 \pm 0.01$ & $0.09 \pm 0.02$ & $0.11 \pm 0.04$ \\
\hline $20: 4 n 3$ & $0.4 \pm 0.1$ & $0.4 \pm 0.1$ & $<$ & $0.6 \pm 0.2$ & $0.53 \pm 0.06$ & $0.62 \pm 0.07$ & $0.8 \pm 0.2$ \\
\hline $20: 5 n 3$ & $1 \pm 1$ & $1.2 \pm 0.9$ & & $2 \pm 1$ & $9 \pm 1$ & $8 \pm 2$ & $7 \pm 2$ \\
\hline $22: 1 n 11$ & $2.9 \pm 0.8$ & $2.8 \pm 0.7$ & $>$ & $1.6 \pm 0.7$ & $2 \pm 1$ & $2 \pm 1$ & $2 \pm 2$ \\
\hline 22:1n9 & $0.9 \pm 0.2$ & $0.9 \pm 0.2$ & $>$ & $0.6 \pm 0.2$ & $0.4 \pm 0.2$ & $0.5 \pm 0.3$ & $0.6 \pm 0.4$ \\
\hline $21: 5 \mathrm{n} 3$ & $0.33 \pm 0.07$ & $0.34 \pm 0.06$ & & $0.30 \pm 0.07$ & $0.49 \pm 0.07$ & $0.56 \pm 0.05$ & $0.6 \pm 0.1$ \\
\hline $22: 5 n 3$ & $6 \pm 1$ & $6 \pm 1$ & & $5.3 \pm 0.9$ & $4.9 \pm 0.7$ & $4.3 \pm 0.8$ & $4.3 \pm 0.9$ \\
\hline $22: 6 n 3$ & $6 \pm 1$ & $7 \pm 1$ & & $7 \pm 1$ & $9 \pm 2$ & $9 \pm 2$ & $12 \pm 2$ \\
\hline 24:1n9 & $0.14 \pm 0.04$ & $0.14 \pm 0.04$ & & $0.2 \pm 0.1$ & $0.06 \pm 0.03$ & $0.11 \pm 0.08$ & $0.18 \pm 0.09$ \\
\hline
\end{tabular}

had significantly higher values in the inner layer, while the saturated acids 15:0, 16:0 and 18:0, the monounsaturated acid 18:1n7, and the polyunsaturated acid 20:4n3 had lower values in the inner layer.

When all 28 FAs were included in a PCA, the distinction between the inner and outer layer was incomplete (Fig. 2). This was largely due to variation between individual polar bears, which was the largest source of variation in the data ( $46 \%$ of the total), and therefore manifested along PC 1 . The differences between layers were responsible for $18 \%$ of the total variation in the data, evident along PC 2 (Fig. 2).

When a PCA was carried out on the basis of the 10 FAs that were significantly different between layers (Table 1), the layer difference became the most prominent difference, accounting for $61 \%$ of the total variation (Fig. 3). The samples from the inner and outer layers were then completely separated, except for Bears 4 and 9. Clear exceptions were evident compared to the other 16 bears, which may have been caused by inadequate sample handling (see 'Materials and methods').
Differences among the individual bears were also apparent in the PC-plot in Fig. 3, i.e. along the second PC. The plot shows that the individual variance in the inner and outer adipose tissue was correlated because each bear was positioned approximately in the same position along PC 2.

The values for the FA compositions of the blubber for the 3 seal species are presented in Table 1 and Fig. 1. These are average values for all determinations within a species, i.e. 90 separate samples from 10 ringed seals, 195 samples from 10 harp seals and 125 samples from 9 bearded seals. The variances around the means are due to individual differences between animals and differences between the blubber layers.

The FA composition of the blubber of each seal species was significantly different from that of the inner adipose tissue of the polar bears $(p<0.01)$ for all 28 FAs. These differences were larger than the differences among the 3 seal species, or the differences between the polar bear adipose tissue layers. In the case of 14 of the FAs, the relative amounts in the 


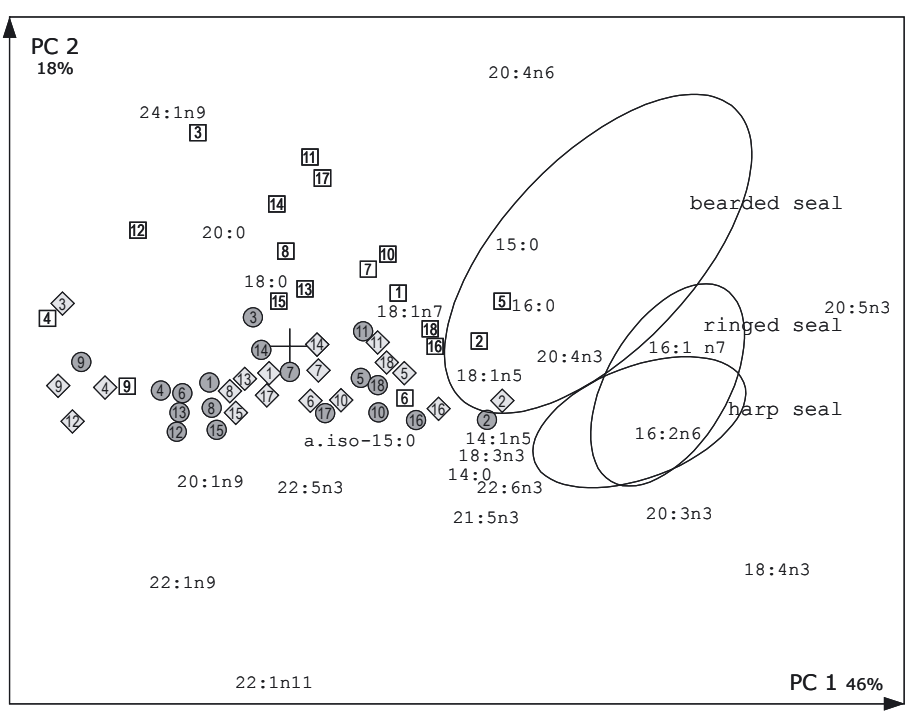

Fig. 2. Ursus maritimus, Phoca hispida, Phoca groenlandica and Erignathus barbatus. Principal component biplot of adipose tissue samples from 18 polar bears based on all 28 variables, i.e. fatty acids. Circles represent samples from the inner tissue, diamonds the middle tissue, and squares the outer tissue. Each symbol represents the average of 2 parallel samples. The individual identification number of the bear is given within the symbols. The location of the fatty acids in the plot indicates their importance for the spread of the samples, with those farthest from the origin along a $\mathrm{PC}$ having a higher importance for that $\mathrm{PC}$, and consequently for the position of the samples in the plot. (The 4 fatty acids with the lowest importance, i.e. situated close to the origin, are not shown). Samples of blubber from the 3 prey species (90 samples from 9 ringed seals, 195 samples from 10 harp seals and 125 samples from 9 bearded seals) are projected onto the PC plot of the polar bear samples, without being included in the principal component analysis. They are located within the 3 ovals

blubber of all 3 seal species were higher than the relative amounts in polar bears. In $8 \mathrm{FAs}$, the relative amounts in the blubber of all 3 seal species were lower than the amounts in polar bears. Only 5 FAs in polar bears had relative amounts that fell within the range of relative values among the 3 seal species. The seal samples appear on one side of the bear samples in the PC plot (Fig. 2). Only a few of the samples of bearded seals overlapped with the bear samples.

A space-filling model of the inner adipose tissue samples from the bears was computed. This box model was based on 2 significant PCs. The outer limit of the model, i.e. the RSD, at the $99 \%$ level was 0.69 . All samples with a RSD above this value are significantly different from the model of the inner adipose tissue (Fig. 4). Only one of the samples from the inner adipose tissue was an outlier, according to the model. Most of the samples from the middle adipose tissue layer were inside the model, reflecting the similarity between the 2 innermost layers. Almost all samples from the outer layer were outside the model. All the seal samples were significantly different from the inner layer of the bear adipose tissue.
This RSD plot only shows the difference between the inner bear adipose tissue and the other samples, not the direction of the differences, which is shown in the PC plot in Fig 2. The outer bear adipose tissue lies in one direction from the inner adipose tissue, while the seal blubber samples lay perpendicular to this. This indicates that different FAs were responsible for the differences in the 2 cases.

\section{DISCUSSION}

Polar bears are opportunistic feeders and they do occasionally forage on white whales Delphinapterus leucas, walrus Odobenus rosmarus, birds, eggs, reindeer Rangifer tarandus platyrhynchus and other carrion (Calvert \& Stirling 1990, Smith \& Sjare 1990, Stempniewicz 1993, Derocher et al. 2000), in addition to phocid seals, which make up the bulk of their diet (Smith 1980, Stirling \& Øritsland 1995). The diet of polar bears is obtained principally from the marine food web (Ramsay \& Hobson 1991, Hobson \& Stirling 1997). In the Barents Sea - Svalbard area - the diet is found to consist almost exclusively of ringed, bearded and harp seals (Lønø 1970, Derocher et al. 2002). Harp seals have only been found in the diet during the summer season (April/May to October). Since the bears in the present project were sampled in mid-April, we assume they had eaten mostly ringed and bearded seals during the 6 mo prior to sampling.

Since seals from the 3 species were not available in the area during the time we were sam-

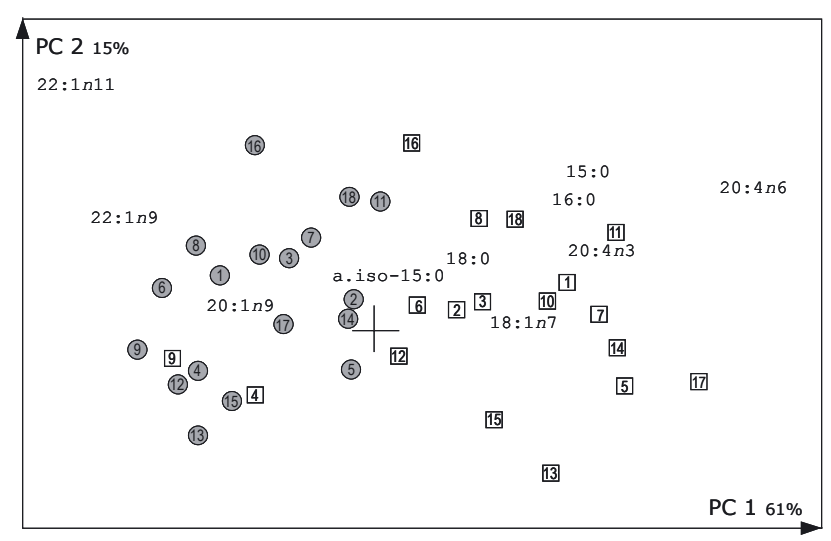

Fig. 3. Ursus maritimus. Principal component biplot of inner and outer adipose tissue samples of 18 polar bears based on the 10 fatty acids with significant differences between the layers (see Table 1). Circles represent samples from the inner tissue and squares the outer tissue. Each symbol represents the average of 2 parallel samples. Individual identification numbers of each bear is given in the symbols 


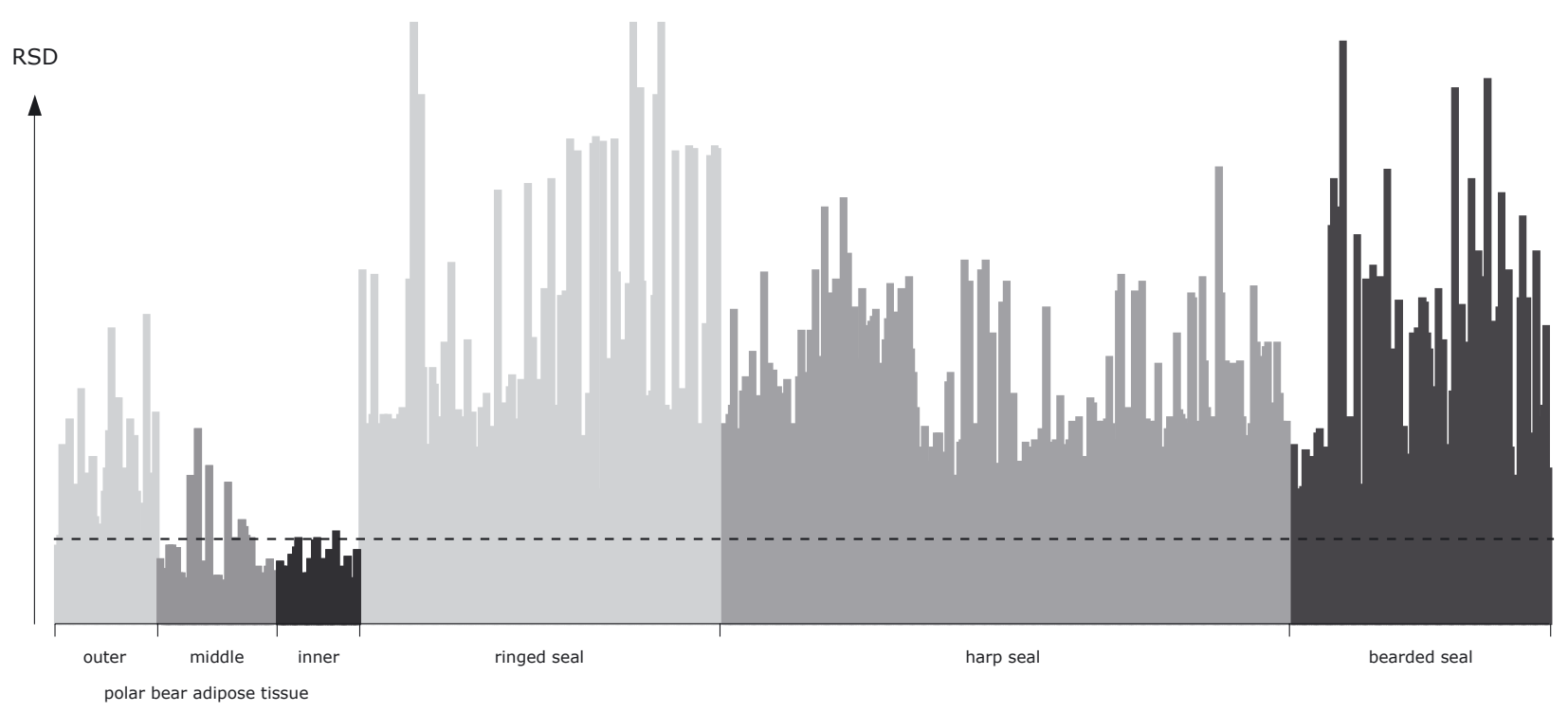

Fig. 4. Ursus maritimus, Phoca hispida, Phoca groenlandica and Erignathus barbatus. SIMCA bar-plot of the distances of all samples, measured as residual standard deviation (RSD), from the space-filling model of the samples of the inner adipose tissue of the polar bears. The rejection criterion, i.e. outer limit of the model based on $95 \%$ confidence limit, was 0.69 , and is indicated by the dashed line. For explanation of SIMCA and RSD, see 'Materials and methods'

pling the bears, the seals were collected over a larger geographic area and time frame. However, since both the predator and the prey are wide-ranging animals, an investigation of this type, carried out in the wild, has to cope with such divergences.

The FA composition of the seal blubber, at least of the inner blubber, will change with the time of year due to changes in the condition of the animals, which is caused by fasting, feeding, and their reproductive status, e.g. lactation. Changes in the seals' diet may also have an impact on the composition of the blubber. In an experiment with captive juvenile harp seals, a change in diet from herring Clupea harengus (fat) to pollock Pollachius virens (lean), with large differences in FA composition, resulted in a change in the seals condition, i.e. body fat declined by $32 \%$ (Kirsch et al. 2000). The relative change in amounts of various blubber FAs was in the order of 10 to $20 \%$ in Kirsch et al.'s (2000) study. Nevertheless, intra-species variation in FA composition is much smaller than the difference between the various phocid seal species and the polar bear. In the present investigation, the difference between the FA composition of the blubber of the various seals and the adipose tissue of the polar bears was dramatic for most of the FAs.

Despite considerable variation among individual bears in the composition of their adipose layers, significant stratification was observed between the inner layer and outer layer in polar bear adipose tissue. This stratification was less pronounced than that commonly observed in seals and whales which have a quite distinct gradient through their blubber (Fredheim et al.
1995, Olsen \& Grahl-Nielsen 2003). The blubber of seals and whales is stratified because it is not merely a storage place for lipids (energy). The blubber of these animals is important for insulation, heat dissipation, buoyancy regulation and body streamlining. These functions require specific compositions of various FAs through the blubber column.

The smaller and different degree of stratification in the adipose tissue of polar bears shows that this tissue is not adapted to serve the same functions as the blubber of the seals. Because of the thick fur of the polar bear, with specialized hair structure that is thermally beneficial (Frisch et al. 1974), the temperature gradient in the blubber column is almost certainly smaller than the gradient found in seals and whales. Thus, the small vertical changes in the FA composition of the polar bear adipose tissue are in line with Pond et al.'s (1992) suggestion that although the superficial adipose tissue of polar bears provides some insulation, it is not anatomically adapted to be an insulator.

A common feature of polar bear adipose tissue and seal blubber is the relatively high amounts of the longchain monounsaturated acids 22:1n11, 22:1n9 and 20:1n9 present. But polar bears did not have the relative enrichment of saturated FAs 14:0, 16:0 and 18:0 in the inner blubber and the enrichment of the monounsaturated acids $14: 1 \mathrm{n}-5,16: 1 \mathrm{n}-7$ and $18: 1 \mathrm{n}-9$ in the outer blubber which is typical of seals (Käkelä et al. 1993, Fredheim et al. 1995).

The FA composition of the adipose tissue of the polar bears was significantly different from the composition of the blubber of the 3 seal species that are thought to 
be their major prey in the Barents Sea region (Table 1, Figs. 1-3). The most striking differences were much larger relative amounts of 18:1n9 and 20:1n9 in the bears. The bear adipose tissue was systematically enhanced in terms of long-chain FAs compared to the lipids in seal blubber, with higher amounts of the saturated FAs with 18 and 20 carbons, and the monounsaturated acids with 20, 22 and 24 carbons, while the 14and 16-carbon saturated and monounsaturated acids were present in higher relative amounts in seal blubber compared to the bear's adipose tissue. Apparently, the seal blubber provides the bears with a dietary mixture of FAs that is too fluid to be used directly as building blocks for the triacylglycerols in bears, which are subjected to much higher temperatures than the outer blubber of seals.

Polar bears, like all mammals, have enzymes that promote FA elongation and $\Delta 9$-desaturation; the activities of these enzymes are regulated following tissue-specific needs (Kouba et al. 1999, Ntambi 1999). In the adipose tissue of the polar bear, chain elongation of FAs seems to be more active than in seal blubber. The higher ratio of $18: 1 n 9 / 16: 1 n 7(\Delta 9-18: 1 / \Delta 9-16: 1)$ in the polar bear suggests that the primary product of cytosomal FA synthesis, $16: 0$, is mainly elongated first, and therafter $\Delta 9$-desaturated. This is different than the case in seals, where the relative activity of $\Delta 9$-desaturation is obviously higher than the elongation activity, thus producing more 16:1n7. In fact, the polar bears resemble other bears and other terrestrial predators, which deposit a lot of 18:1n-9 but less 16:1n-7 in their adipose tissues (Käkelä \& Hyvärinen 1996). Active chain elongation may also contribute to the higher ratio of 20:1n9/18:1n9 in polar bears.

In addition to saturated and monounsaturated FAs, the ingested polyunsaturated fatty acids (PUFAs), are also metabolized further in the tissues of the predator. It is obvious that the polar bears are not simply storing the lipids from their prey directly, without modification in their adipose tissue. After absorption and hydrolysis of dietary lipids, selective uptake of FAs circulating in the blood can occur (Ackman \& Cunnane 1992), which leads to selective incorporation of different FAs into the triacylglycerols of adipose tissues. In the tissues, chain elongation, peroxisomal chain shortening and $\Delta 6$ - and $\Delta 5$-desaturations can modify the PUFAs and change the original FA composition in a speciesspecific way. This can result in a unique FA composition of the adipose tissue of the predator, which is distinctly different from that of the prey.

The largest deviation in the relative amounts of individual PUFAs between the polar bears and their diet was the very low content of $20: 5 n 3$ ( 1 to $2 \%$ of total FA) in the polar bear adipose tissue compared with the relative amounts in the blubber of the seals ( 7 to $9 \%$ of total FA). In addition, 18:4n3 was present in much lower concentrations in the bears. Some of these n-3 PUFAs may have been metabolised further into 22:5n3, since the relative amount of this FA was higher in the polar bear adipose tissue than in the diet. Some of the n-3 PUFAs may also have been used for the formation of structural lipids of the organs and for production of important biologically active local tissue hormones and signal molecules, i.e. eicosanoids (Ackman \& Cunnane 1992, and references therein).

The relative amounts of n-6 PUFAs: $18.2 n 6,20: 2 n 6$ and 20:4n6, did not differ very much between the bears and seals in this study. On the other hand, 16:2n6 occurred in approximately half the relative amount in the bear adipose tissue compared to the seal blubber, which may arise from the tendency of the seals to incorporate short-chain acids into their blubber, and the tendency of the polar bear to elongate the short and fluid fatty acids, i.e. 16:2n6 to 18:2n6.

All of these selective changes in the FA composition between the prey and predator show that the differences in the FA composition of the different dietary items would have to be very large in order to leave a pattern that would survive the metabolic rearrangements in the body and tissues of the predator. Interestingly, the blubber of 4 captive polar bears had a very different FA composition from that of the wild polar bears in this study (Colby et al. 1993). The captive bears had smaller relative amounts of 20:5n3 and 22:6n3, but higher amounts of 18:3n 3 than wild bears. These and other differences were ascribed to the diet, which was very different from the polar bears' natural diet. The diet was rich in bread, fruit and other plant matter, and in horsemeat, beef and chicken, and low in fish. Colby et al. (1993) did not exclude the possibility that physiological differences in absorption, incorporation, modification or de novo synthesis of lipids may have influenced the composition of the bears' blubber. However, the interpretation of the data from the 4 captive polar bears in Colby et al.'s (1993) study is also obscured by the fact that the bears were all older than $24 \mathrm{yr}$ and in such poor condition that they were put to death. The samples for adipose tissue analysis were collected postmortem.

In the adipose tissue of the Svalbard polar bears, all but 5 of the 28 FAs occurred either in higher or lower amounts than the corresponding FA in any of the main prey species. Consequently, the composition of polar bear adipose tissue is not a simple combination of the compositions of their prey species, and any influence the relative availability of different prey species in the Svalbard area might have on the FA composition of the blubber would not be simple to deduce. Thus, the FA pattern of the bear's adipose tissue does not lead to simple conclusions regarding the relative contribution that different prey species might make to their $\operatorname{diet}(\mathrm{s})$. 
Acknowledgements. We thank R. Käkelä for his comments on the manuscript and A.-K. Halvorsen and C. Lid for skilful technical assistance.

\section{LITERATURE CITED}

Ackman RJ, Cunnane C (1992) Long-chain polyunsaturated fatty acids. Sources, biochemistry and nutritional/clinical applications. Adv Appl Lipid Res 1:161-215

Calvert W, Ramsay MA (1998) Evaluation of age determination of polar bears by counts of cementum growth layer groups. Ursus 10:449-453

Calvert W, Stirling I (1990) Interactions between polar bears and overwintering walruses in the Central Canadian High Arctic. Int Conf Bear Biol Manage 8:351-356

Colby RH, Mattacks CA, Pond CM (1993) The gross anatomy, cellular structure, and fatty acid composition of adipose tissue in captive polar bears (Ursus maritimus). Zoo Biol 12:267-275

Dahl TM, Lydersen C, Kovacs KM, Falk-Petersen S, Sargent J, Gjertz I, Gulliksen B (2000) Fatty acid composition of the blubber in the white whales (Delphinapterus leucas). Polar Biol 23:401-409

Derocher AE, Wiig Ø, Bangjord G (2000) Predation of Svalbard reindeer by polar bears. Polar Biol 23:675-678

Derocher AE, Wiig Ø, Andersen M (2002) Diet composition of polar bears in Svalbard and the western Barents Sea. Polar Biol 25:448-452

Fredheim B, Holen S, Ugland KI, Grahl-Nielsen O (1995) Fatty acid composition in blubber, heart and brain from phocid seals. In: Blix AS, Walløe L, Ulltang $\varnothing$ (eds) Whales, seals, fish and man. Elsevier, Amsterdam, p 153-168

Frisch J, Øritsland NA, Krog J (1974) Insulation of furs in water. Comp Biochem Physiol A 47:403-410

Grahl-Nielsen O, Hammill MO, Lydersen C, Wahlstrøm S (2000) Transfer of fatty acids from female seal blubber via milk to pup blubber. J Comp Physiol B 170:277-283

Hammill MO, Smith TG (1991) The role of predation in the ecology of the ringed seal in Barrow Strait, Northwest Territories, Canada. Mar Mamm Sci 7:123-135

Hobson KA, Stirling I (1997) Low variation in blood $\mathrm{d}^{13} \mathrm{C}$ among Hudson Bay polar bears: implications for metabolism and tracing terrestrial foraging. Mar Mamm Sci 13: 359-367

Iverson SJ (1993) Milk secretion in marine mammals in relation to foraging: can milk fatty acids predict diet? Symp Zool Soc Lond 66:263-291

Iverson SJ, Frost KJ, Lowry LF (1997) Fatty acid signatures reveal fine scale structure of foraging distribution of harbor seal and their prey in Prince William Sound, Alaska. Mar Ecol Prog Ser 151:255-271

Iverson SJ, Stirling I, Lang S (1999) Using blubber fatty acids for ecological insight: the example of foraging behavior of polar bears. Abstracts from the 13th Biennial Conference on the Biology of Marine Mammals, The Society for Marine Mammalogy, Hawaii

Käkelä R, Hyvärinen H (1996) Site-specific fatty acid composition in adipose tissues of several northern aquatic and terrestrial mammals. Comp Biochem Physiol B 115:501-514

Käkelä R, Hyvärinen H, Vainiotalo P (1993) Fatty acid composition in liver and blubber of the saimaa ringed seal (Phoca hispida saimensis) compared with that of the ringed seal (Phoca hispida botnica) and grey seal (Halichoerus grypus) from the Baltic. Comp Biochem Physiol B 105:553-565
Kirsch PE, Iverson SJ, Bowen WD (2000) Effect of low-fat diet on body composition and blubber fatty acids of captive juvenile harp seals (Phoca groenlandica). Physiol Biochem Zool 73:45-59

Kouba M, Hermier D, Le Dividich J (1999) Influence of a high ambient temperature on stearoyl-CoA-desaturase activity in the growing pig. Comp Biochem Physiol B 124:7-13

Kvalheim OM, Kvarstang TV (1987) A general-purpose program for multivariate data analysis. Chemom Intell Lab Syst 2:235-237

Lønø O (1970) The polar bear (Ursus maritimus Phipps) in the Svalbard area. Norsk Polarinstitutt Skrifter 149:1-115

Ntambi JM (1999) Regulation of stearoyl-CoA desaturase by polyunsaturated fatty acids and cholesterol. J Lipid Res 40: 1549-1558

Olsen E, Grahl-Nielsen O (2003) Blubber fatty acids of minke whales: stratification, population identification and relation to diet. Mar Biol 142:13-24

Pond CM, Mattacks CA, Colby RH, Ramsay MA (1992) The anatomy, chemical composition, and metabolism of adipose tissue in wild polar bears (Ursus maritimus). Can J Zool 70:326-341

Ramsay MA, Hobson KA (1991) Polar bears make little use of terrestrial food webs: evidence from stable-carbon isotope analysis. Oecologia 86:598-600

Ramsay MA, Stirling I (1988) Reproductive biology and ecology of female polar bears (Ursus maritimus). J Zool (Lond) 214:601-634

Smith TG (1980) Polar bear predation of ringed and beared seals in the land-fast sea ice habitat. Can J Zool 58: 2201-2209

Smith TG, Sjare B (1990) Predation of belugas and narwhals by polar bears in nearshore areas of the Canadian High Arctic. Arctic 43:99-102

Stempniewicz L (1993) The polar bear Ursus maritimus feeding in a seabird colony in Frans Josef Land. Polar Res 12: 33-36

Stirling I, Archibald WR (1977) Aspects of predation of seals by polar bears. J Fish Res Board Can 34:1126-1129

Stirling I, McEwan EH (1975) The calorific value of whole ringed seals (Phoca hispida) in relation to polar bear (Ursus maritimus) ecology and hunting behaviour. Can J Zool 53:1021-1027

Stirling I, Øritsland NA (1995) Relationships between estimates of ringed seal (Phoca hispida) and polar bear (Ursus maritimus) populations in the Canadian Arctic. Can J Fish Aquat Sci 52:2594-2612

Stirling I, Spencer C, Andriashek D (1989) Immobilization of polar bears (Ursus maritimus) with Telazol ${ }^{\circledR}$ in the Canadian Arctic. J Wildl Dis 25:159-168

Ugland KI, Massart GJ (1996) Klassifisering. In: Nortvedt R, Brakstad F, Kvalheim O, Lundstedt T (eds) Norsk Kjemisk Selskps Faggruppe for Kjemometri, Bergen, Norway, p 153-157

Walton MJ, Henderson RJ, Pomeroy PP (2000) Use of blubber fatty acid profiles to distinguish dietary differences between grey seals Halichoerus grypus from two UK breeding colonies. Mar Ecol Prog Ser 193:201-208

Watts PD, Hansen SE (1987) Cyclic starvation as a reproductive strategy in the polar bear. Symp Zool Soc Lond 57: 305-318

Wold S (1976) Pattern recognition by means of disjoint principal component models. Pattern Recogn 8:127-139

Wold S (1978) Cross validatory estimation by means of the number of components in factor and principal component models. Technometrics 20:397-406

Submitted: August 22, 2003; Accepted: October 30, 2003

Proofs received from author(s): December 10, 2003 